\title{
An Analysis of Linguistic Discourses and Literary Techniques in Meena Kandasamy's Select Works
}

\author{
J. Sangeetha \\ Kalasalingam Academy of Research and Education, Anand Nagar, Krishnankoil 626126, Tamil Nadu, India
}

\begin{abstract}
S. Mohan
Faculty of English, Kalasalingam Academy of Research and Education, Anand Nagar, Krishnankoil 626126, Tamil

Nadu, India
\end{abstract}

A. Hariharasudan

Faculty of English, Kalasalingam Academy of Research and Education, Anand Nagar, Krishnankoil 626126, Tamil

Nadu, India

R. Kannan

Faculty of English, Hindustan Institute of Technology and Science, Chennai, Tamil Nadu, India

\begin{abstract}
Language becomes the vulnerable person's first offensive weapon, one that will spark a debate, show shortcomings, and compel others to take sides. It is a fundamental medium for engagement and communication. It not only represents and interprets facts and observations, but it also has an impact on people's views and actions because it is an integral aspect of society's cultural conditions. As a result, the current research will concentrate on the language and linguistics aspects of notable Indian writer Meena Kandasamy and her well-known works such as Touch (2006), Ms. Militancy (2010), The Gypsy Goddess (2014) and When I Hit You (2017). The study's findings reveal that Kandasamy's work transcends the boundaries of postcolonial mobility and diversity by demonstrating the material and the subject matter's resolute tenacity, authenticity, and rawness.
\end{abstract}

Index Terms — authenticity, defense, language, linguistics, society

\section{INTRODUCTION}

In the world of literature, Indian English Literature has established itself as a distinct entity. Indian writing in English covers a broad array of topics. Indian writers - poets, novelists, literary critics, and playwrights - have made significant contributions to world literature from the pre-independence era. Since, this writing serves to represent cultural identity, custom, societal standards, and even Indian history through portrayals of Indian life and Indians living worldwide, current Indian English fiction has aimed to express the Indian reality of contemporary adversity. Beyond being a unique and outstanding, rather dynamic native flare - up of intellectuals, Indian Writing has matured into a new type of Indian culture and voice with which India frequently interacts.

One of the most notable features of Indian English writing is that the background is Indian, and the language, despite being foreign, has adapted to the needs of Indians. For instance, Rao abbreviates, "In recent times, India English as well as Indian Writing in English has got its own identity" (Rao, 2019). The growth of a substantial body of Indian literature in English demonstrates how Indians appropriate English for their own convenience and in accordance with aboriginal cultural contexts. The entry of everyday voices in multiple registers became a gateway to innovative linguistic expressions in Indian English literature, and this multilingual and multicultural version of English has gained its own identity. It is to these writers' credit that they have mastered the complexity of the language and internalized the hues and variety of the Indian subcontinent, overcoming the challenges of writing in a language other than English and establishing a distinctive style for themselves.

A number of recent Indian writers have made significant contributions to the literary canon. When it comes to Women's writing in English, several Women writers in India are making vast strides that maintain pace with the rest of the world. They were the pioneers in communicating to readers a wide range of native Indian issues, interposed by a strong feminist perspective. One such writer is, Meena Kandasamy, a notable Indian writer whose works has received prestigious awards and recognition around the world. She is one of the most eminent Indian writers of our time and undeniably one of India's most successful authors. Kandasamy's candour as a writer surpasses reader's wildest 
expectations. According to Kandasamy, Language becomes the unarmed person's first weapon of offense, one that will start an argument, one that will expose flaws and inspire people to take sides.

As a writer, she differs considerably from other Indian women novelists in the context of open heartedness and frank narration. She is the last women to care for what others say about her. Her style has a vivacity that breaks away from rigid writing conventions and breaks down traditional barriers in writing. Meena Kandasamy's poetic voice, which Anjum Hassan likened to a revelation, alternates between darkness of desperation and light of active rebellion states, "Meena Kandasamy is a feisty new entrant into the duck pool called Indian English Poetry" (Hassan, 2007). The primary objective of this research is to analyse the various narrative strategies and to assess the language style used by Meena Kandasamy in her renowned works. The study's novelty comes from the researchers' meticulous examination of Kandasamy's writings, which has never been done before, giving the current study more validity and uniqueness.

\section{REVIEW OF LITERATURE}

Damrosch characterizes a work of literature as changing when it moves from a regional to an international work (Wood, 170). World literature today encompasses works that transcend geographical boundaries and have an impact on people all around the world. These works not only convey authenticity, but they also employ a number of techniques, such as symbolism and surrealism, that have not been critically examined by other authors (Benjamin, 1999). What has arisen is a literary legacy that, in its quest to reestablish its group's integrity, provides a content and structure in contrast to the mainstream Indian literature. Subjugated societies can, however, challenge established patterns of writing by generating their own aesthetics and narrative practices if literature embodies the ideals of the group in which the narrative resides. According to certain critics, this occurs when what is deemed to have 'literary value' is rewritten in order to make visible what is considered to be other manifestations of agony (Sharma, 2021; Festino, 2015). In this approach, we identify adversity within our own community by transforming individuals into superheroes or saints, but we neglect the misery of those outside our ethical framework on two different levels: by failing to acknowledge their suffering and by failing to recognise their experiences as literatures. This can be related to the words of Morris (1996) where he states, "I would say that not all narratives count as literature" because, sadly, "[...] not all sufferings matter." One such category of literature is the marginalized literature, which not only challenges established canons, but also seeks to create new ones. It seeks to reject conventions and cultural norms that not only marginalise the daily voice, but also the voices of other oppressed communities, including women.

It tries to create a new paradigm, a new set of values that can be applied to the current cultural situation. This literature can be seen as part of the global postmodernist culture. It reveals a collective psyche of a community whose voice had been silenced throughout history (Nigam, 2000). The reality of this literature, like the language of this reality, is different. It emphasises the faithful depiction of the heartrending marginalized people's experience in terms as plain as possible, using the unrefined, impolite spoken language, the dialect that is peculiar to a region, wherever possible (Whitehead, 2009). In contrast to the rules of conventional standard literature, which focuses on objectivity and universality of literature, marginalized writing frequently emphasises subjective narratives (Brueck, 2011). Poetry, fiction, theatre, and autobiography are all examples. The plot, characters, and situations are all controlled by the idea. These writers have repeatedly asserted that the criteria used to evaluate mainstream literature are irrelevant to the study of marginalized literature. Limbale (2021) explains why separate aesthetics are necessary: "This kind of literature is not pleasure-giving literature. As a result, the aesthetics of narrative style cannot be based on standards that prioritise pleasure derived from beauty." It also rejects the classical aesthetic's purely artistic tradition, arguing that the depiction of the harsh realities of life cannot be judged by the same criteria that are used to evaluate artistic pleasure. All narrative elements - plot, character, and dialogue - in narratives are subordinated to the central thought or idea (Gajarawala, 2011).

\section{Methodology}

This section of the research looks into Meena Kandasamy's narrative techniques and linguistic strategies in relation to her renowned works. On the first hand, the genre of Poetry, according to Meena Kandasamy, is a response to the passive, unbiased, and shielded language of political statements, sociological writing, and journalistic writing. Poets like Meena Kandasamy have ventured to devise a woman's language through the realm of poetry in the endeavour to build one's own space. Kamala Das remarks, "Once again after long years of search I came into contact with the power of honest poetry when I was reading Meena Kandasamy's anthology" (Venkatesan and James, 2018).

According to Kandasamy, a woman's stillness should be broken by breaking forth in a torrent of speech. As a result, her narratives place her in a position of militancy. She revels in and derives twisted joy from debunking illusions that deny women, their freedom to live, learn, and to choose. Kandasamy proclaims, "I do not write into patriarchy. My Maariamma bays for blood. My Kali kills. My Draupadi strips. My Sita climbs on a stranger's lap. All my women militate. They brave bombs, they belittle kings. They take on the sun, they take after me" (Kandasamy, 2010; Saxena, 2015). She disputes the impression of sanctity and virginity associated with Sita or Draupadi. These historical women, such as Sita or Draupadi, are no longer "gendered subalterns" in Kandasamy's writings, but free thinkers and rebels. This suggests that these are not silent or dominating voices; rather, they are new voices emerging from the margins of 
society, where language is changing and growing at the same time. It reveals a community's collective consciousness, whose voice had been silenced throughout history. She continues to say:

Yes. Poetry, it is raw. It is real. It is full of jagged edges. My poetry is naked, my poetry is in tears, my poetry screams in anger, my poetry writhes in pain. My poetry smells of blood, my poetry salutes sacrifice. My poetry speaks like my people, my poetry speaks for my people (Kandasamy, 2010).

The caustic poetry, which is loaded with sharp cynicism, not only shocks or exasperates the readers, but also challenges them to reconsider time-honored myths and conventions that are at the heart of Indian culture. Her poetry is written in a deliberately gloomy and perilous tone, as the verses passionately slay patriarchal stereotypes. Such distorted language deviates from the traditional pattern of linguistic structure used in the portrayal of women. The prevalence of semiotic flux renders poetry's language fluid, poetic, and subversive, foreshadowing social transformation. Kandasamy, in Ms. Militancy writes "This tongue allows me to resist, rape, to rescue my dreams. It is not man-made...My language is dark and dangerous and desperate in its eagerness to slaughter your myths" (Kandasamy, 2010).

It is apparent in most of her works that she promotes feminism through authoritative words and the style of writing. For her, writing appears to be a kind of freedom and resistance. Kandasamy's use of discourse concretizes her desire to express and fight for non-dominant women: their desires, dreams, autonomous ideas, and speaking for themselves rather than being continually spoken for or of by the patriarchal conventional order and their male counterparts (Pratibha, 2017). Her language is so scathingly effective that it has developed into an intricate yet a blatant tool of political opposition stand out. Kandasamy in an interview with Shobha Warrier asserts that, "The poet in me will not exist without the activist in me. Even my love poems are obscurely political. Writing lets me be an activist" (Warrier, 2012).

Similarly, Kandasamy's When I Hit You (2017), which was shortlisted for the Women's Fiction Prize, the UK's most prestigious prize for women writers, focuses on women's empowerment and addresses women not to tolerate anything that obstructs their progress. For this purpose, she has incorporated her own autobiographical narrative of her horrible wedding experience and how she was freed from the shatters of the patriarchal system into the narrative, providing readers with a true image and the intensity of abuse behind closed doors rather than just depicting fictitious characters. She encourages women who are trapped in an abusive relationship to leave the relationship without regard for societal restraints and to lead their lives on their own. She says: "A Woman being abused can mostly trust only one person for help. Herself' (Kandasamy, 2017).

Meena Kandasamy's poetry is not just about women experiences; she speaks for the entire community that has been marginalised by society's dominating elements (Jacob, 2018). She uses various techniques to her poetry for which she can be aptly called an outstanding poet, who transforms poetic themes into prose in order to locate her own writing as a sort of generating meaning. For instance, the poem titled "Liquid Tragedy: Karamchedu 1985" published in the poetry collection Touch exemplifies this very well:

$$
\begin{gathered}
\text { Buffalo Baths. Urine. Bullshit } \\
\text { Drinking Water for the Dalits } \\
\text { The very same Pond. } \\
\text { Practice for eons. } \\
\text { A bold Dalit lady } \\
\text { dares to question injustice. } \\
\text { Hits forth with her pot. Her indignation } \\
\text { is avenged. Fury let loose. Violence. Rapes. } \\
\text { Killings. Self-seeking politicians shamelessly } \\
\text { consult History-"If there was a way out then, } \\
\text { there shall be a way out now." Succor arrives with } \\
\text { Esteemed Father of our Nation. His Samaadhi speaks: } \\
\text { If Harijans don't get water in this village, let them } \\
\text { set on a sojourn elsewhere. The rotten example } \\
\text { is obeyed. Casting behind cruel memories } \\
\text { Dalits exit - weary of the persecution } \\
\text { And wander all over the nation. } \\
\text { Again, a Dalit Exodus. } \\
\text { Total Surrender. }
\end{gathered}
$$

The essential theme of Kandasamy in this poem is raw and outwardly unrestrained works are active resistance or revolutionary activism, the language that seeks to assess what needs to change and resolve issues (Arora, 2020). Accordingly, this poem illustrates the true and horrible incident of a massacre happened in Karamchedu, Andhra Pradesh. Her unfettered flow of words without regard for customary rules, as well as the shape in which she coins the poem, demonstrates her rebellious attitude in the fight for equality. The technical innovations she introduces in the style of poetry appear to suit her rebellious personality flawlessly.

Primarily, the writings of Kandasamy make irregular use of vernacular words that place the work in a distinct spatial and cultural location, as the author admits to using Taminglish instead of English. Kandasamy employs English 
language as a medium to demonstrate the culture of her homeland, India, to international readers. She expresses this in a poem titled "Mulligatawny Dreams":

i dream of an english

full of the words of my language.

an english in small letters

an english that shall tire a white man's tongue

an english without the privacy of its many rooms

an english with suffixes for respect

an english with more than thirty six words to call the sea

an english that doesn't belittle brown or black men and women

an english of tasting with five fingers

an english of talking love with eyes alone (Kandasamy, 2006).

This poem is a clash of linguistic realities; the author wishes for an English that functions like the language of Tamil. She conjures forth the essence of the land with no capital letters and substantial tamil imagery. She portrays Tamil as a language rich in peculiarities, idiosyncrasies, elegance, and romanticism. Through this it is very well apparent that Kandasamy's works are works of World Literature because, by taking on the role of a conscientious social poet aware of her historical responsibility, she writes a creative lyrical verse that not only critiques ubiquitous forms of subordination, but also fervently hopes for yet-to-be-born future prospects (Alwar, 2016). For instance:

We will rebuild / worlds from shattered glass / and remnants of holocausts. Once impaled for our faith / and trained to speak in voiceless whispers / we'll implore / you to produce the list / from hallowed memories / of our people disgraced/ as outcastes / degraded / as untouchable

So / now/ upon a future time/ there will be a revolution. It will begin in our red-hot dreams that surge that/ scorch that / scald that sizzle like lava / but never settle down never / pungently solidify (Kandasamy, 2006).

The above poetic lines from the poem "We Will Rebuild Worlds", demonstrates the shift from first person narration, 'I,' to first person plural, 'we,' emphasizing the interconnectedness between the individual and the society in an explicit manner. Kandasamy's poetry straddles the line between India and the rest of the world. Her poetry is effectual and meaningful, and it is ingrained yet worldwide.

Kandasamy distinguishes herself as an extraordinary writer in narrating the history of a true massacre in her documentary The Gypsy Goddess by her stunning use of language. The Gypsy Goddess chosen as the Independent newspaper's debut of the year and was nominated for several awards, including the International Dylan Thomas Prize is a powerful, lyrical account of Kilvenmani and its aftermath that defies many established rules while remaining brutally true to its original concept - recounting a horror that had been relegated to non-existent pages in mainstream Indian literature (Muralidharan, 2018). It has also been translated into several languages all over the world.

In this novel, Kandasamy's linguistic discourse deviates from the standard story or plot framework. Her stories are incredible, legendary, and full of complicated tales of ordinary people who have lived and thrived in implausible, almost miraculous ways. Kandasamy's distinctiveness and talent reside in her narrating approach. Alternative narrative, first and third person narrative, stream of consciousness approach, narrative in the form of letters and diaries, myth, and magical realism are some of the literary styles she has utilized in her novel. The author employs concept of 'Heteroglossia,' by Bakhtin which refers to a type of speech in which multiple diverse voices coexist within a single language. Moreover, Bakhtin himself defines Heteroglossia as "another's speech in another's language, serving to express authorial intentions, but in a refracted way" (Bakhtin, 2017). Similarly, Kandasamy employs a variety of voices in her writing, including Gopakrishna Naidu, Maayi, Ramalingam, Ratnam, and the author herself, to mention a few.

Kandasamy achieves realism in the realm of her narrative like our thalaivar, our village headman; thannikkaarar, the watermen; Saanippaal, Cowdung mixed with water; Mirasdars - land owners; Cheri, slum; Vellaikkaaran - foreigner, Burma arisi - a special type of rice cultivated in Tanjore, India. She explains not just the meanings of specific regional words, but also the meanings of complicated sentences and expressive expressions, enabling her national heritage to be known to a global audience. For example, Kaalula neruppa kattikittu odanum, adhunaaala thappichom, We escaped because of our flaming feet." She even employs mythologies like the "notorious, anklet-wearing vampire," as well as proverbs such as "...the crow who attempted to walk like a swan never managed to mimic its grace, instead he lost even his natural gait," give the anecdote a regional feel.

Kandasamy's narrative rhetoric and conversations emerge through the interaction of cultural reunions as they are coded in reader behaviour and languages in evaluating the text's meanings (Bhadras, 2018). She uses a variety of inquiries as a postmodern strategy to arouse passive readers and cause them to reflect and question about world events. "The Gypsy Goddess" is fragmentary, non-linear in space and time, self-reflexive, and unconventional in every sense. Within a larger discourse on novelistic writing, the author displaces her own re-framing of the novel. Rather, the novel frames historical events as a commentary on the novelist's work, conveying the reader, interfering with the story, and anticipating potential oppositions to her writing. She constructs an image of her readers with her choice of words by first questioning them, compelling them to think for themselves. This can be seen in the following passage where she writes: 
Why can't you follow a standard narrative format? If the reader wanted a straight, humourless version of the events that surrounded the single biggest caste atrocity in India, she would read a research paper in the Economic and Political Weekly or a balanced press report. If the reader wants to understand the myriad landowning patterns in the Tanjore District, she will read an academic treatise ...For all my shortcomings, I will not force you to follow any linear or non-linear logic where hate travels along a lattice-bridge and arrives a predestined location (Kandasamy, 2014).

On the other hand, Kandasamy writes non stop without any pause illustrating the plight of the victims. The two page long narrative of the massacre is hurled in one long sentence that lacks pauses about which Dolores Herrero observes that the "...distorted grammar is a laudable attempt to pay respect to the incommensurable anguish experienced by those traumatized survivors..." (Herrero, 2017). The discovery of new linguistic possibilities, challenges dominant ideologies by subverting established practices. She expresses her defiance through her language. She uses a variety of strategies to make her and her novel stand out. When questioned in an interview, What happened to a novel's rules?, for which Kandasamy claims "are hanging on [her] clothesline over there" (Kandasamy, 2014). She goes on to state that she deliberately chose not to seek praise, recognition, or prizes with her work but to strive for a humanitarian cause. Thus, Meena Kandasamy succeeds in using language as a tool to sow awareness, distinctiveness, and a dynamic and changing perspective to reality in the minds of her readers.

It is evident that Kandasamy feels that poetry entails a "pressing responsibility to ensure that language is not at the mercy of the oppressors" (Herrero, 2017). The ways of the status quo, on the other hand, are subtle, and Kandasamy recognises that a socially astute poet must be true to herself in order to be an authentic rebellious voice and confrontation. Her writing reveals the boundaries of postcolonial mobility and multiculturalism by revealing the obstinate firmness, if not exacerbation, of binary forms of authenticity in the face of uneven globalization (Menozzi, 2020). The main influence is a proof that a marginalized group can become militant, creative, and progress in an adversarial society. Kandasamy's narrative thus enforces a deeper confirmation that is expressed not as abandonment and diversion through mobility, but as a stern firmness to assume responsibility for a common cause (Herrero, 2017).

\section{CONCLUSION}

The present study abbreviates language and linguistics aspects of Meena Kandasamy's notable works. The texts are analysed in terms of ideologies and theories proposed by eminent theorists. As a result, the study's findings conclude that Kandasamy's investigative writings enable him to tackle readers with murder, awful hostility, blatant discrimination, and an unfair and intolerable reality that no classic realist novel could have illustrated with such sensitivity, allowing readers to become a part of the victim's and his or her community's historical understanding. The research, though discussed extensively, has some limitations. This study deals with the linguistic aspects, onamastics, morphology, dialect and unique narrative techniques in the works of Meena Kandasamy, excluding other potential themes portrayed in her works. The limitations of the present study give scope and recommend for the auxiliary studies that the future research can be carried out in the areas of feminism, equality, violence, emancipation and so on.

\section{REFERENCES}

[1] Alwar, S. (2016). Meena Kandasamy's Poetry as World Literature. Ashvamegh Indian Journal of English Literature, 2(11). 1518.

[2] Arora, P. (2020). Analysing the Use of Language in Meena Kandasamy's The Gypsy Goddess. Research Journal of English, 5(2). 75-88.

[3] Bakhtin, M. (2017). The dialogic imagination: Four essays. University of Texas Press.

[4] Benjamin, W. (1999). Selected Writings 1931-1934, vol. 2, Part 2. Trans. Rodney Livingstone and Others. Eds. Michael W. Jennings, Howard Eiland, and Gary Smith. Harvard University Press.

[5] Bhadra, S. (2018). A 'Space' of One's Own: Exploring the Language of Resistance in Select Poems of Meena Kandasamy. An Interdisciplinary Journal of Literary Studies, 3(2), 93-100.

[6] Brueck, L. R. (2011). Marking the boundaries of a new literary identity: The assertion of 'Dalit consciousness in Dalit literary criticism. Religion and Identity in South Asia and Beyond, 347-368. Retrieved September 14, 2021, from https://doi.org/10.7135/upo9780857288110.016

[7] Festino, C. G. (2015). Dalit women life-narratives and literature as experience. Acta Scientiarum. Language and Culture, 37(1), 25. Retrieved August 18, 2021, from https://doi.org/10.4025/actascilangcult.v37i1.23930

[8] Gajarawala, T. (2011). Some Time between Revisionist and Revolutionary: Unreading History in Dalit Literature. PMLA, 126(3), 575-591. Retrieved September 28, 2021, from doi:10.1632/pmla.2011.126.3.575

[9] Hassan, A. (2007). "Anger is the engine of Kandasamy's poems." Rev. of Touch, by Meena Kandasamy. The Hindu. Retrieved September 9, 2021, from https://www.kandasamy.co.uk/books-etc.

[10] Herrero, D. (2017). Postmodernism and politics in Meena Kandasamy's the gypsy goddess. The Journal of Commonwealth Literature, 54(1), 70-83. Retrieved August 26, 2021, from https://doi.org/10.1177/0021989417719118

[11] Jacob, J. (2018). The poetry of Meena Kandasamy: A tool of political dissent. Medium. Retrieved September 8, 2021, from https://medium.com/@JerinAnneJacob/the-poetry-of-meena-kandasamy-a-tool-of-political-dissent-f024c320eae.

[12] Kandasamy, M. (2006). Touch. Peacock Books.

[13] Kandasamy, M. (2014). The gypsy goddess. Atlantic Books.

[14] Kandasamy, M. (2016). Ms Militancy. Navayana Pub. 
[15] Kandasamy, M. (2018). When I hit you: Or, a portrait of the writer as a young wife. Europa Editions.

[16] Limbale, S. (2021). Towards an Aesthetic of Dalit Literature: History, Controversies and Considerations (Marathi Edition). Orient BlackSwan.

[17] Menozzi. (2020). World literature, non-synchronism, and the politics of Time. Springer International Publishing.

[18] Morris, D. B. (1996). Social suffering. Daedalus, 25(1), 25-45.

[19] Muralidharan, K. (2018). Fifty Years of Keezhvenmani Massacre, in Literature and Film. The Wire. Retrieved August 28, 2021, from https://thewire.in/caste/keezhvenmani-massacre

[20] Narayana Rao, K. S. (2019). The Indian Novel in English: A Search for Identity. Studies in the Novel, 51(1), 26-32. Retrieved September 7, 2021, from https://doi.org/10.1353/sdn.2019.0004

[21] Nigam, A. (2000). Secularism, Modernity, Nation: Epistemology of the Dalit Critique. Economic and Political Weekly, 35(48), 4256-4268.

[22] Pratibha. (2017). English in Dalit Context: Reading Poetry by Meena Kandasamy. GNOSIS, 3(4), 86-96.

[23] Saxena, S. (2015). 'My Draupadi Strips, My Sita Sits on a Stranger's Lap': Fiery Writer Meena Kandasamy Speaks. Youth Ki Awaaz. Retrieved August 29, 2021, from https://www.youthkiawaaz.com/2015/02/meena-kandasamy-internview/.

[24] Sharma, B., \& Kumar, A. (2021). Outsider-Within: The Sociological Significance of Dalit Women's Life Narratives. Interventions, 1-16. Retrieved August 22, 2021, from https://doi.org/10.1080/1369801x.2021.1892505

[25] Venkatesan, S., \& James, R. (2018). Mapping the Margins: An Interview with Meena Kandasamy: Conducted at Sacred Heart College in Kochi, India on 12 November 2015. ARIEL, 49(1), 143+. Retrieved August 30, 2021, from https://link.gale.com/apps/doc/A531978596/LitRC?u=anon c1bf2221\&sid=googleScholar\&xid=fdd567bd

[26] Warrier, S. (2012). “They don't like women who are flamboyant about sexuality.” Rediff. Retrieved August 27, 2021, from https://www.rediff.com/news/report/they-dont-like-women-who-are-flamboyant-about-sexuality/20120521.html

[27] Whitehead, P. (2009). Restructuring norms and reducing cultural divides between prisons and probation: A cautionary note. Criminal Justice Matters, 77(1), 8-9.

J. Sangeetha was born in Madurai, India in 1996. She has completed her Post Graduate Degree from Lady Doak College, Madurai in 2019 and she is currently pursuing her PhD in full time at Kalasalingam Academy of Research and Education, Tamil Nadu, India. Her research interests include emerging trends in contemporary literature, Feminism and Indian Literature.

S. Mohan is a faculty of English at Kalasalingam Academy of Research and Education, Tamilnadu, India. He has been teaching a number of courses on World Literatures and Language Teaching over the years, as well as more general courses in Communicative English, Business Communication and Soft skills. His research and publication interests include ESP, ELT, African-American Literature and Education. He has published and presented more than fifty articles in various reputed journals and conferences. He was also served as an External Examiner for PhD scholars in different universities and Associate Editor, Editorial member in various International Journal Publication at home and abroad.

A. Hariharasudan has been working as a faculty member of English in Kalasalingam Academy of Research and Education (formerly known as Kalasalingam University), Tamil Nadu, India. His research in Ph.D. is post-modern readings of Indian Fiction. $\mathrm{He}$ is also serving as Language Editor to the reputed Scopus \& WoS Indexed Journal-Polish Journal of Management Studies, Poland. He published numerous research articles related to English Language, Literature, Education 4.0 and conducted multi-disciplinary research too. His research interest is on Postmodernism, Digital English, English for Specific Purpose, Business English, Education 4.0 and Industry 4.0. ORCID: 0000-0002-7938-9383.

R. Kannan is an Associate Professor in the Department of Languages, Hindustan Institute of Technology and Science, Chennai, India. His research interests include ELT and Literature. He has published research articles in reputed national and international journals besides being actively participating in national and international conferences. He is a certified Speaking Examiner for Business English Certificate Courses by Cambridge Assessment English, UK. Recognized research supervisor for Ph.D and an External Examiner for Ph.D. Scholars in different Universities across India. 